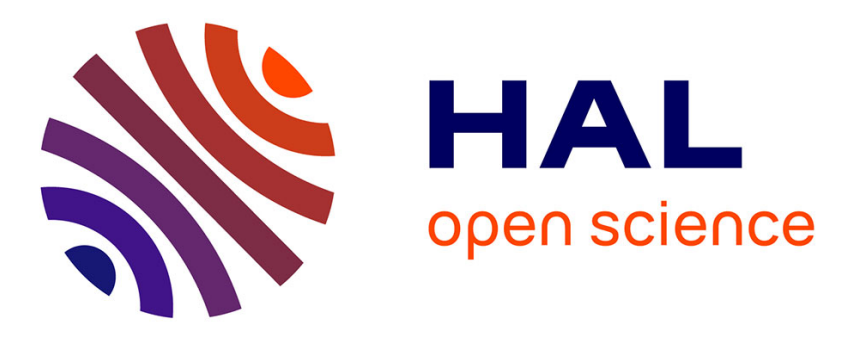

\title{
Feasibility of the reuse of total and processed contaminated marine sediments as fine aggregates in cemented mortars
}

Julien Couvidat, Mostafa Benzaazoua, Vincent Chatain, Ahmed Bouamrane, Hassan Bouzahzah

\section{To cite this version:}

Julien Couvidat, Mostafa Benzaazoua, Vincent Chatain, Ahmed Bouamrane, Hassan Bouzahzah. Feasibility of the reuse of total and processed contaminated marine sediments as fine aggregates in cemented mortars. Construction and Building Materials, 2016, 112, pp.892-902. 10.1016/j.conbuildmat.2016.02.186 . hal-01308108

\section{HAL Id: hal-01308108 \\ https://hal.science/hal-01308108}

Submitted on 27 Apr 2016

HAL is a multi-disciplinary open access archive for the deposit and dissemination of scientific research documents, whether they are published or not. The documents may come from teaching and research institutions in France or abroad, or from public or private research centers.
L'archive ouverte pluridisciplinaire HAL, est destinée au dépôt et à la diffusion de documents scientifiques de niveau recherche, publiés ou non, émanant des établissements d'enseignement et de recherche français ou étrangers, des laboratoires publics ou privés. 


\title{
Feasibility of the reuse of total and processed contaminated marine sediments as fine aggregates in cemented mortars
}

Julien Couvidat $^{1}$, Mostafa Benzaazoua ${ }^{1,2, *}$, Vincent Chatain ${ }^{1}$, Ahmed Bouamrane $^{1}$, Hassan Bouzahzah ${ }^{2}$

${ }^{1}$ Université de Lyon, INSA Lyon, LGCIE - DEEP (Déchets Eau Environnement Pollutions), EA4126, 69621 Villeurbanne Cedex, France

${ }^{2}$ UQAT-Polytechnique, IRME (Institut de Recherche en Mines et Environnement (IRME), 445 Boul. de l'Université, Rouyn-Noranda, J9X 5E4 Canada

* Corresponding author. Tel.: (+1) 8197620971 \#2404; fax: (+1) 819797 4727. E-mail address: mostafa.benzaazoua@uqat.ca (M. Benzaazoua).

\begin{abstract}
In a context promoting waste sustainable management, dredged sediments are assessed for valorization as substitute for sand in non-structural cemented mortars. Full substitution of sand by total sediment revealed low mechanical performances at UCS testing, linked to a high porosity. However, mechanical strength was improved, and porosity reduced, by using $80 \mu \mathrm{m}-$ sized sediment. Thus, porosity is correlated to the presence of a fine fraction and its constitution, which brought a higher water demand during formulation. This research confirmed that the reuse of the coarser fraction of a marine sediment offered an interesting valorization potential as cemented mortars for non-structural applications.
\end{abstract}

Keywords: marine sediment; inorganic contaminants; desliming; mineralogical assessment; mechanical behavior. 


\section{Introduction}

Harbors experience constant silting-up as a result of continental erosion and anthropogenic runoff. Consequently, regular dredging is required for the proper administration of harbors, generating large quantities of mineral wastes, classified in the European List of Waste by the Commission Decision 2000/532/EC. Up to 18.6 million tons of sediment (expressed as dry matter) were dredged in France (metropolitan and overseas) in 2010, and 33.56 million tons in 2009 (Le Guyader, 2013). Trace metals such as copper, zinc, lead or mercury are frequently encountered at various levels in marine sediments (Caplat et al., 2005; Casado-Martínez et al., 2009; Chatain et al., 2013a; Lions et al., 2010). Once dredged, such contaminated materials need to be adequately managed, in accordance with existing regulations, otherwise metals may be mobilized during weathering events (Caplat et al., 2005; Chatain et al., 2013b; Lions et al., 2007).

Until the early 90s, dredged sediments were in most cases disposed of at deeper seas or deposited on land. Both methods are inexpensive, but today dumping at sea is strictly regulated by the 1996 international protocol of the London convention and OSPAR convention (OSPAR commission, 2009), and upland disposal is only available for harmless sediments depending on local regulations. By the way, upland disposal on proof surfaces have been also used as a bioremediation technique when carefully monitored by conducting regular aeration of the contaminated sediments, to enhance degradation of organic contaminants and/or metal removal (Juhasz and Naidu, 2000; Lovley and Coates, 1997; Van Hullebusch et al., 2005). The alternative for most total contaminated materials is storage in landfill sites, which is costly and requires the careful monitoring of eluates. Treatment and reuse is therefore encouraged by European and national guidelines, but applications still remain very limited (Akcil et al., 2014). 
Diverse treatments and reuse options are available, such as Portland cement production (Dalton et al., 2004), or brick production (Cappuyns et al., 2015; Hamer and Karius, 2002; Samara et al., 2009; Xu et al., 2014), sometimes after application of an effective treatment such as the Novosol® process combining combustion and phosphatation (Agostini et al., 2007; Lafhaj et al., 2008; Samara et al., 2009; Zoubeir et al., 2007). Among the available treatments, the use of a hydraulic binder with contaminated sediments couples an effective and inexpensive way to treat metallic contamination together with a solution for reuse in construction materials in certain mortar uses. After treatment to reduce their water content, dredged sediments are interesting for use in some geotechnical applications as in road basement construction, or backfill (Dubois et al., 2009; Rekik and Boutouil, 2009; Wang et al., 2012). The cost/performance ratio can be controlled by adjusting the cement proportion and admixtures addition, depending on the final use. In this case, immobilization of trace metals occurs through physical and chemical processes, by reducing permeability and porosity as well as a chemical fixation thanks to the creation of a nanometer-level gel structure with calcium-silicate-hydrate (CSH) phases.

Few studies have been conducted on the substitution of sand by dredged sediments in cemented mortars for civilian engineering use (Dubois et al., 2011), as most studies deal with a simple stabilization-solidification process (Chen et al., 2009; Gardner et al., 2007; Paria and Yuet, 2006; Zentar et al., 2012). In the case of a valorization process, cement proportions are usually higher to improve the mechanical behavior, and admixtures can be added to improve durability or other formulation parameters such as workability. Dredged sediments can fully substitute for sand aggregate (Ben Allal et al., 2011; Yan et al., 2014), as well as be used in partial substitution with co-valorization of other solid wastes (Wang et al., 2015). Another possibility is to use 
dredged sediments as a fine granular corrector with a coarser aggregate (Limeira et al., 2011, 2010). The cement percentage is usually between 15 and 35\%, depending on the targeted use.

Furthermore, valorization of dredged sediments within cemented mortars may be limited by the high content of organic matter and/or clays as well as soluble sulfates production, which is often associated to major metal contamination (Chinchón et al., 1995; Harvey et al., 2010; Rajasekaran, 2005). These compounds being usually contained within the finest fraction, a particle size separation pretreatment may be applied before reuse to improve mortars mechanical behavior as well as to separate the recoverable fraction from the most contaminated one. Hydrocycloning for example may be used for separating the contaminated fine fraction (desliming) from the coarser one during the dredging, with further appropriate management of the polluted and less voluminous fraction as a dangerous waste.

In the present study, the work aim to evaluate the feasibility of reusing a raw and a weathered contaminated dredged sediments to fully replace sand in cemented mortars in a simple sustainable management technique. For this purpose, granulometric-chemistry distribution will be studied in order to determine the impact of a particle size separation on contamination. The contamination being proven as restrained in the fine fraction, a size cutoff treatment have been applied on both sediments (raw and weathered), and the mineralogical and physical impact on microstructure will be assessed. Mechanical behavior of formulated mortars will be evaluated and compared on basis of a simple unconfined compressive strength (UCS) test. 


\section{Material \& methods}

\subsection{Aggregates and hydraulic binders}

The two sediments assessed in this study come from the same sampling site, a harbor located in the south of France, where they were dredged with a mechanical shovel. The raw sediment was immediately placed in barrels after dredging with a marine water layer above to preserve the oxido-reduction state, and stored in a cold chamber in darkness at $4^{\circ} \mathrm{C}$. The weathered sediment (labeled as 'Weath' in figures and tables) was sieved at 20mm and deposited outside to undergo natural aging after a short aeration pretreatment (bioremediation, which consists of regular mechanical turning to enhance bacterial degradation of organic contaminants). As part of a larger project, both sediment samples were stored for 5 years to assess the effect of a natural weathering. Prior to characterization, samples of sediments were homogenized by quartering and stored at $4{ }^{\circ} \mathrm{C}$ in darkness. Prior to cement formulation, sediments were dried in a furnace at $45^{\circ} \mathrm{C}$ in order to avoid oxidation of the oxidizable fraction. These sediments are denoted as raw total and weathered total and labeled in mortars respectively ' $R$ ' and ' $W$ '. Two hydraulic binders were used to prepare the mortars, blast furnace slag (Slag) and ordinary Portland cement (PC). Due to the marine origin of those sediments and their high content in chlorides and sulfides, slag was chosen to be assessed in the mortar formulations to improve the long-term durability towards sulfate and chlorides attack (Benzaazoua et al., 2004; Rajasekaran, 2005). Reference mortars were made with technical sand for comparison purposes.

\subsection{Granulometric chemistry study}

Particle-mass distribution of chemical content was evaluated according to an internal method adapted from the XP P 94-041 method by wet sieving in 10 increasing mesh size sieves (25 $\mu \mathrm{m}, 40 \mu \mathrm{m}, 63 \mu \mathrm{m}, 80 \mu \mathrm{m}, 140 \mu \mathrm{m}, 200 \mu \mathrm{m}, 500 \mu \mathrm{m}, 1 \mathrm{~mm}, 2 \mathrm{~mm}, 5 \mathrm{~mm})$ with tap water, then 
measuring the dry weight of each fraction. Six fractions $(0-25 \mu \mathrm{m}, 25-80 \mu \mathrm{m}, 80-200 \mu \mathrm{m}, 200$ $1000 \mu \mathrm{m}, 1-2 \mathrm{~mm},>2 \mathrm{~mm}$ ) were analyzed for total content analysis at SARM (Service d'Analyse des Roches et Minéraux, CNRS, Vandoeuvre-lès-Nancy) with a routine ICP-MS method (Carignan et al., 2001).

After analysis of the results, a particle size separation cut-off is chosen based on the repartition of metallic contaminants in fine fraction. Both total sediments were sieved in wet way similarly to the previous particle-mass distribution analysis method to valorize the coarse fraction as a basic component in cemented mortars. Mesh size cutoff will be specified later in Results section concomitantly to the granulometric chemistry results. Processed sediments will be labeled as raw processed ('RP') and weathered processed ('AP').

\subsection{Mortar preparation and conditioning}

The required amounts of mortar ingredients (dried sediments or sand, binding agent, and mixing water) were thoroughly mixed and homogenized in a double spiral concrete mixer for about 10 min to ensure homogeneity of the final paste. Mixing water was added progressively until the targeted paste consistency was reached (slump $=61 \mathrm{~mm} \pm 2 \mathrm{~mm}$ on the Abrams cone). The mixtures were continuously mixed at a low to medium mixing speed (about 250-300 rpm). Immediately after mixing, samples were cast in 2 inch diameter, 4 inch high cylindrical hermetically closed molds in three layers, each tamped 25 times with an iron rod to remove most of the air pockets within the sample. Cemented mortar samples were then sealed and cured for 14, 28 and 90 days in a humidity chamber controlled at $25{ }^{\circ} \mathrm{C}$ and more than $90 \%$ of relative humidity. 


\subsection{Sediment and mortar characterization}

\subsubsection{Aggregate and hydraulic binder characterization}

The Gs of each sample was measured with a helium gas pycnometer (Micromeritics Accupyc 1330). Analysis of major and trace metals in the sediments was performed by ICP-AES (Inductively Coupled Plasma - Atomic Emission Spectroscopy, model Perkin Elmer Optima $3100 \mathrm{RL}$ ) after a $\mathrm{HNO}_{3} / \mathrm{Br}_{2} / \mathrm{HF} / \mathrm{HCl}$ digestion carried out on a hot plate, and in mortar components by X-Ray Fluorescence (XRF) spectroscopy (Niton XL3t 900SHE). Before chemical elemental analysis, solid samples were prepared by grinding to a fine powder to facilitate their digestion. Particle-mass distribution was determined accordingly to the method previously described in the "Granulometric chemistry study" section. Total carbon was evaluated by an induction furnace analyzer (ELTRA CS-2000). Content of OM was determined by TOC through sample combustion in a furnace heated to $680^{\circ} \mathrm{C}$. The released gas was then analyzed with a non-dispersive infrared gas apparatus. The PSD analysis was carried out by laser diffraction (Malvern Mastersizer 2000G) after sieving the sediment at 1mm mesh. During the PSD analysis, ultrasound was applied for 1 min to allow breakdown of the aggregates.

The mineralogy of samples was determined by X-ray diffraction (XRD) on a Bruker AXS D8 advance diffractometer equipped with a copper anticathode, scanning over a diffraction angle

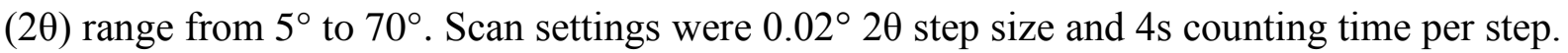
The DiffracPlus EVA software (v.9.0 rel.2003) was used to identify mineral species and the TOPAS software (v 2.1) implementing the Rietveld refinement was used to quantify the abundance of all the identified mineral species (Young, 1993). The absolute precision of this quantification method is of the order of $\pm 0.5-1 \%$ (Bouzahzah et al., 2008; Raudsepp and Pani, 2003). The samples mineralogy identification was completed by optical microscopy 
observations on polished sections prepared with bulk sediment samples impregnated in an epoxy resin. Optical microscopy was carried out by reflected light microscopy (Zeiss Axio Imager.M2m) and allowed to define selected area for further SEM examination. Thus, the chemical composition of the individual minerals (stoichiometry) was determined using a scanning electron microscope (Hitachi S-3500N) equipped with an Energy Dispersive Spectrometer (EDS, Silicon Drift Detector X-Max $20 \mathrm{~mm}^{2}$, Oxford) operated under the INCA software (450 Energy). The operating conditions were $20 \mathrm{keV}, \sim 100 \mu \mathrm{A}$ and $15 \mathrm{~mm}$ working distance.

\subsubsection{Mortar characterization}

At each curing time, formulated mortars were sampled for characterization immediately after the UCS test. The samples were taken in the heart of the cylinder to avoid the exposed surfaces.

Mortar pore waters were immediately characterized after extraction for $\mathrm{pH}$ and soluble sulfates after each UCS test. An 1:2 solid/liquid ratio was used, with an extraction time of 5 minutes ; then, solution was vacuum-filtered at $0.15 \mu \mathrm{m} . \mathrm{pH}$ was measured on the filtrate using a portable multi-meter (VWR SympHony SB90M5) equipped with a $\mathrm{pH} \mathrm{Ag} / \mathrm{AgCl}$ electrode (Fischer AccupHast 13-620-114). Soluble sulfates were determined by automated spectrophotometry (Thermo Fisher Scientific Aquakem Photometric Analyzer) using a method adapted from NF T 90-040.

Free water content was determined by drying mortar samples at $40^{\circ} \mathrm{C}$ for $48 \mathrm{~h}$ until the mass stabilized, in triplicates. This temperature was chosen to avoid the dehydration of cementitious minerals, in particular $\mathrm{C}-\mathrm{S}-\mathrm{H}$ and to preserve sulfides from oxidation. The remaining of the analyses were performed on stove-dried samples. 
The pore structure network of the dried mortar samples was then characterized using a mercury intrusion porosimeter (MIP) (Micromeritics Autopore III 9420). Pressures ranging from 0 to $414 \mathrm{MPa}(60,000 \mathrm{psi})$ were applied to measure the throat pore diameter to $0.003 \mu \mathrm{m}$. MIP was analyzed according to the ASTM D 4404 standard. Representative mortar samples were taken after UCS testing as far as possible from the shear zone, and oven-dried at $50{ }^{\circ} \mathrm{C}$ for at least $24 \mathrm{~h}$ before testing.

Thermal analysis was used for the identification of cementitious mineral phases and aggregate components (Gabrovšek et al., 2006; Sha et al., 1999). TGA/DSC tests were performed using the SDT Q600 apparatus from TA Instruments which allows simultaneous recording of weight loss and heat flow during thermal treatment of the sample. The thermal behavior of samples was registered in an inert nitrogen atmosphere at a rate of $20^{\circ} \mathrm{C} / \mathrm{min}$ up to $800{ }^{\circ} \mathrm{C}$ with a $30 \mathrm{~min}$ delay at $50{ }^{\circ} \mathrm{C}$ to remove free water from the samples. Approximately $35 \mathrm{mg}$ of material, placed in a $90 \mu \mathrm{L}$ alumina cup and covered by an alumina lid, was used for each test.

\subsubsection{Mechanical testing}

The mechanical behavior of cured mortars was assessed at each curing time by performing uniaxial compression tests. Determination of their unconfined compression strength (UCS) was realized on a MTS hydraulic press $(50 \mathrm{kN}$ capacity and $1 \mathrm{~mm} / \mathrm{min}$ deformation rate). Each test was triplicated to ensure its validity. Before the trials, the samples were rectified to obtain a length to diameter ratio $(L / D)$ of 2 with an accuracy of $1 \mathrm{~mm}$. The UCS presented hereafter is the mean value of the three replications. Compression tests were performed after 14, 28 and 90 days of curing to evaluate the short term (14 days), medium term (28 days) and long term (90 days) strength for all mortars. 


\section{Results}

\subsection{Granulometric chemistry study of total sediments}

Trace and major elements distribution was assessed through 7 size fractions in both total raw and weathered sediments, compared to the respective mass of each fraction (Table 1). Masssieving distribution clearly shows the high weight percentage of the fine fraction $(<25 \mu \mathrm{m})$ in both raw and weathered total sediments (53.5 vs. 48.5 wt.\%). In raw sediment, trace metals are not exclusively distributed in the finest fraction $<25 \mu \mathrm{m}$ even though 41 to $53 \%$ of metals are concentrated in this fraction. Contrariwise, in the weathered sediment the $<25 \mu \mathrm{m}$ fraction contains between 78 and $85 \%$ of $\mathrm{Cu}, \mathrm{Pb}$ and $\mathrm{Zn}$. The fraction under $25 \mu \mathrm{m}$ contains $41.3 \%$ of $\mathrm{Cu}, 53.1 \%$ of $\mathrm{Pb}$, and $49.4 \%$ of $\mathrm{Zn}$, whereas the fine fraction of weathered sediment contains respectively $81.8,84.8$ and $78.3 \%$ of $\mathrm{Cu}, \mathrm{Pb}$ and $\mathrm{Zn}$. Bioremediation and weathering during aging probably caused a shift of trace metals from the coarse fraction to the fine fractions, by probable oxidation of sulfides followed by adsorption on fine particles as clays or ironoxihydroxides, or chelation by organic matter(Caille et al., 2003; Calmano et al., 1993; Claff et al., 2010; Lions et al., 2007). In raw sediment, $\mathrm{Cu}$ is also found at high concentrations (30\% of total $\mathrm{Cu}$ ) in the $200-1000 \mu \mathrm{m}$ fraction $(13.4 \mathrm{wt} . \%)$, and to a lesser extent $\mathrm{Zn}(23.8 \%$ of total $\mathrm{Zn})$.

On the purpose of studying the effective reuse of a dredged sediment, sieving of fine particles may be studied as an alternative to the whole reuse in cemented mortars, with the intention to valorize coarser fractions and managing a lower quantity of contaminated waste. In this context, both raw and weathered sediments have to be deslimed. Granulometric chemistry was used to determine the size cut-off in order to enhance trace metals decontamination of sediments. Contaminated fine fractions have to be adequately managed with an efficient treatment and 
storage. Indeed, $\mathrm{Cu}, \mathrm{Pb}$ and $\mathrm{Zn}$ are highly concentrated in the finest fraction of both sediments, particularly for the weathered one. Based on these results, size cut-off was so set at $80 \mu \mathrm{m}$.

\subsection{Sediment and mortar components characteristics}

The physical, chemical and mineralogical characteristics of total and processed raw and weathered sediments are presented in Table 2, as well as Portland cement, slag and sand characteristics.

The measured Gs of total and processed sediments are very similar $\left(2.5 \mathrm{vs.} 2.7 \mathrm{~g} / \mathrm{cm}^{3}\right)$, close to the Gs of quartz and carbonate minerals which are usually the predominant constituents of sediments. This assumption is confirmed by XRD mineralogy; quartz (15.7 vs. 15.3 wt.\%), calcite $\mathrm{CaCO}_{3}$ (31.1 vs. 38.9 wt.\%) and dolomite $\mathrm{CaMgCO}_{3}$ (6.8 vs. 13.6 wt.\%) being the major well-crystallized minerals in both sediments. The sieving treatment only impacted the weathered $>80$ sample, with an increase of about $0.2 \mathrm{~g} / \mathrm{cm}^{3}$. For PSD, the fine fraction of both total sediments seems similar with $\mathrm{D}_{50}(19.2 v s .22 .1 \mu \mathrm{m})$, but $\mathrm{D}_{90}$ shows that the coarse fraction is higher in the raw material $(152.7 \mu \mathrm{m})$. The mass distributions of cumulated sieved fractions at 63 and $25 \mu \mathrm{m}$ show that the proportion of fine particles is greater in raw than in weathered sediment (59.1 vs. 53.2 and 53.5 vs. 48.5 wt.\% for raw and weathered sediments respectively). The particle mass distribution of the sand material indicates that $76 \%$ of particle mass is between 63 and $500 \mu \mathrm{m}$, unlike the two total sediments which are mainly composed of fine particles.

The chemical characteristics of sediments indicate that carbon is a major constituent (9.3 vs. 9.9 wt. \%), mainly as organic matter since TOC represents about $60 \%$ of the carbon (5.8 vs. 6.3 wt.\%). Other forms of carbon are mainly carbonates, dolomite and calcite, as indicated by XRD mineralogy. Calcium is another major element in the sediments, with a higher concentration in 
weathered (13.9 vs. 19.7 wt.\%) and weathered>80 (16.0 vs. 26.8 wt.\%) sediment. Three major sources of $\mathrm{Ca}$ are suggested by the XRD analysis, with carbonates (dolomite and calcite), and sulfates (gypsum mineral $\mathrm{CaSO}_{4} .2 \mathrm{H}_{2} \mathrm{O}$ for weathered sediment (5.0 wt.\%)). Sulfur content is likewise high, because it can occur in various speciation, in particular as sulfides and sulfates which can be a threating factor against sulfate attacks when formulated in cemented mortars (Rajasekaran, 2005). Sulfur content is about 2 wt.\% in both sediments (1.9 vs. 2.0 wt.\%), but decreases when the sediments are processed (1.1 vs. $1.0 \mathrm{wt} . \%)$. According to SEM mineralogy investigation, sulfur is present as sulfides with pyrite $\mathrm{FeS}_{2}(3.5$ vs. 2.0 wt.\%) in both total sediments, chalcopyrite $\mathrm{FeCuS}_{2}(0.3$ wt.\%) in raw, and sulfates with gypsum in weathered sediment.

The three trace metals assessed, namely $\mathrm{Cu}, \mathrm{Pb}$ and $\mathrm{Zn}$, are highly concentrated in sediments, above the N2 threshold levels according to French legislation (French Official Journal, 2006). Behavior of the total weathered sediment was previously assessed for reactivity. Oxidation still occurs despite the years of weathering, even if in circumneutral conditions the leaching of trace metals remains limited (Couvidat et al., 2015). However, previous studies on trace metal leachability have shown the high sensitivity of such dredged sediments to $\mathrm{pH}$ variations (Chatain et al., 2013b).

\subsection{Mechanical behavior of the mortars}

Total and processed sediments were formulated as cemented mortars, and reference mortars were formulated with generic sand. Mortar mixes characteristics are given in Table 3. Abbreviations PC and S stand for Portland cement and slag in formulations. The cement proportion was fixed at $25 \%$, and slump at $60 \mathrm{~mm}$. These conditions make it possible to compare the water demand of each mix through the Water/Cement (W/C) ratio. Mixtures made 
with raw sediment required more water than those made with weathered sediment, for both total and processed material. However, this ratio decreased strongly with the sediments sizing, approaching that of reference mixtures around 1 ( 0.9 and 1.0 for S-PC and S-PCS), in particular for weathered > 80 mixtures (1.1 and 1.2 for WP-PC and WP-PCS). The removal of fine particles decreases the $\mathrm{W} / \mathrm{C}$ ratio, underlining the well-known role played by fine particles in water adsorption in mortar preparation.

\subsubsection{Total sediment}

Initial strength was low whether mortars are formulated with raw sediment (1.8 and $2.0 \mathrm{MPa}$ for R-PCS and R-PC respectively) or weathered sediment (1.8 and 2.2 MPa for W-PC and WPCS respectively), especially when compared to the strength of reference mortars (12.6 and 12.9 MPa for S-PC and S-PCS respectively) (Fig.1). The mechanical strength increased slightly with curing time for all mortar samples formulated with total sediment, and more importantly for reference mortars. However, final strength of mortar samples formulated with total sediment hardly reached $20 \%$ of the final strength of reference mortars, with UCS values between 2.2 and 3.6 MPa for R-PCS and W-PCS, whereas S-PC and S-PCS reached 16.5 and 17.0 MPa at 90 days. Moreover, the short-term effect of slag on mortars mechanical behavior is negligible: it decreased the raw mortars strength slightly, and increased the weathered and reference mortars strength slightly. The formulation of total sediments as cemented mortars did not reach a satisfactory mechanical strength, even at 90 days, despite the use of slag.

\subsubsection{Processed sediment}

As well as for mortars formulated with total sediment, the mechanical strength of processed sediment-based mortars increased with curing time, except for UCS values of RP-PCS and WPPCS mortars at 28-days whose uncertainties on the results limit the interpretation (Fig. 1). Besides, overall strength was substantially higher than for total sediment-based mortars. Initial 
UCS values of RP-PC and RP-PCS was 5.7 and 4.0 MPa, and 7.3 and 8.2 MPa for WP-PC and WP-PCS. At 90 days, the strength of all the mortars increased, and values of 7.8, 6.3, 11.0, and 10.5 MPa were observed respectively for RP-PC, RP-PCS, WP-PC and WP-PCS. As observed for total sediment-based mortars, the effect of slag on strength at short-term curing time is also negligible.

The use of a sizing cutoff as a sediment treatment allows an effective reuse potential of a moderately contaminated fraction which appears to offer interesting mechanical properties, even if the UCS results of sediment mortars do not reach the level of reference with sand. This discrepancy in mechanical properties is linked to the composition of dredged sediments, which have an influence on the cementation process and thereby on microstructures and mineralogical composition.

\subsection{Mortar characterization}

\subsubsection{Microstructures}

The mortars were characterized in order to highlight the relationship between their mechanical behavior, microstructures and mineralogical composition. In this objective, SEM coupled with a microanalysis spectroscopy has to be used. Figure 2 displays the textures and cementitious phases microstructures of studied mortars.

From a qualitative point of view, no major differences in terms of cement matrixes can be observed between the formulated mortars in the SEM images (Fig. 2). The mortars are noticeably constituted with minerals belonging to the initial aggregates, cemented by probable CSH mineral phases. Some sparse bubbles measuring 50 to $200 \mu \mathrm{m}$ can be observed in all studied mortars, resulting from the initial formulation. However, the microporosity in reference mortars is likely to be thinner than that observed in mortars with total sediments. 
Microstructure was quantitatively assessed by MIP analysis. Figure 3 presents the pore size distribution within the samples. Mixtures formulated with total sediments (Fig. 3a and 3b) appear clearly as highly porous matrices compared to reference mortars (Fig. 3c and 3d), with between 41 and $44 \%$ of cumulative porosity, versus $22-23 \%$ for reference materials. Moreover, porosity of total sediments mortars is larger than that of reference or processed sediments mortars (Fig. 3b and 3d). Mortars with processed sediment are in the same order of magnitude as the reference formulation, with lower porosity values than mortars with total sediments (Fig. 3c). However, RP-PC and WP-PCS have a lower porosity than the reference, with $14-15 \%$ of cumulative porosity.

\subsubsection{Mineralogical characterization}

Mineralogical properties strongly influence the mechanical behavior of mortar formulation, particularly through the formation of typical cementitious mineral phases. Portlandite and CSH are the most abundant products of the hydration reaction of Portland cement, with ettringite and calcium monosulfoaluminate (AFm) (Taylor, 1997). Except for CSH, most of the cementitious phases can be assessed with XRD analysis, which was conducted on mixtures at 28 days of curing for reference mortars and those formulated with total sediments (Table 4). No significant differences are found between mixtures with and without slag. Furthermore, major minerals in the initial aggregates were also detected in mortars. Quartz was identified in all mixtures as well as calcite, in trace amounts for reference mortars, originating probably either from aggregate and/or carbonation during curing. Other minerals such as dolomite, muscovite and sulfides were present in sediment mortars, or as traces. Moreover, the baseline deformation of the diffractograms indicates the probable presence of amorphous minerals such as CSH.

For mortars with raw sediments, some complex sulfate minerals were detected in their corresponding mixtures but because of peaks superposition, their precise identification was 
difficult: they could be either ferrinatrite $\left(\mathrm{Na}_{3} \mathrm{Fe}\left(\mathrm{SO}_{4}\right)_{3} ; 3 \mathrm{H}_{2} \mathrm{O}\right)$ or rapidcreekite $\left(\mathrm{Ca}_{2}\left(\mathrm{SO}_{4}\right)\left(\mathrm{CO}_{3}\right) ; 4 \mathrm{H}_{2} \mathrm{O}\right)$, together with mallardite $\left(\mathrm{MnSO}_{4} ; 7 \mathrm{H}_{2} \mathrm{O}\right)$. These sulfate phases were not observed in raw aggregate and were probably formed during the curing process following the oxidation of sulfide minerals. No portlandite or sulfoaluminate, such as ettringite or AFm minerals, were identified by XRD analysis in raw mortars. In contrast, ettringite and portlandite were detected in mortars with weathered sediments, and only portlandite in reference mortars. Theoretically, ettringite must have been mostly consumed at this point of curing time and transformed into AFm phases. Its presence in W-PC and W-PCS mortars might be the consequence of the high gypsum content of weathered aggregate, added to the gypsum content of Portland and slag binders.

SEM-EDS analyses were also conducted on formulated mortars for mineralogical observations (Fig. 4). As observed in Fig. 2, CSH mineral phases are well-formed in all mortars and no differences can be visually noticed between any of the formulations. Minerals composing the initial aggregates are included within amorphous $\mathrm{CSH}$, such as massive crystals of calcite (Fig. 4c). In addition, hydrates resulting from cement curing detected by XRD analysis are confirmed with SEM. Thin hexagonal portlandite crystals fill some microscopic pores in reference mortars (Fig. 4a and 4b). In fact, portlandite is expected to have mostly precipitated and grown in void volume after 28 days of curing. Less crystallized portlandite can be observed in R-PC mortars with probable entangled minerals (Fig. 4e and 4f). Alumina ferric oxide monosulfate phases (AFm) are also spotted with SEM-EDS, under particular hexagonal imbricated phases in reference mortars (Fig. 4d), but none in either raw or weathered mortars. In fact, after 28 days of curing time ettringite tends to be replaced by AFm phases when the ratio of calcium sulfate to tri-calcium aluminate is low, whereas when this ratio is higher, ettringite is unlikely to convert to AFm (Bapat, 2012). However, CSH phases covered with ettringite needles were 
observed in weathered mortar, and also in raw mortars despite the fact that those minerals were not detected by XRD. In this case, weathered aggregate contributes an extra content of gypsum (Table 2), and raw aggregate contains amorphous sulfides that are easily oxidizable to sulfates during curing (Couvidat et al., 2015). Hence, numerous sulfate phases were detected in raw mortars through XRD, but minerals were poorly identified (Table 4) (Matschei et al., 2007).

\subsubsection{Thermal analysis}

$\mathrm{CSH}$ as a gel undergoes an endothermic dehydration reaction over an extended range of temperature, usually starting from $50^{\circ} \mathrm{C}$ up to $300^{\circ} \mathrm{C}$ in some cases, making it hard to distinguish from other reactions on DTA-DSC graphs (Fig. 5). The first endothermic peak between $50^{\circ} \mathrm{C}$ and $150^{\circ} \mathrm{C}$ can be attributed to the dehydration of $\mathrm{CSH}$, and to ettringite when a DTA peak A is present around $100^{\circ} \mathrm{C}$ (Gabrovšek et al., 2006; Sha et al., 1999). Yet, it appears that ettringite is mostly present in W-PC mortars, and to a lesser extent in R-PC, but very little in S-PC although the endothermic reaction is significant in the three mortars. Therefore, a major contribution to the endothermic reaction may come from $\mathrm{CSH}$ gels in all mortars. An endothermic peak B is also observed in the three mortars around $470^{\circ} \mathrm{C}$, and can be attributed to the dehydroxylation of portlandite. The intensity of this reaction decreases in the following order of samples: S-PC > W-PC > R-PC. This is in accordance with XRD analysis (Table 4), as Portlandite is detected in weathered and reference mortars, although some entangled portlandite is observed in R-PC mortars with SEM-EDS analysis (Fig. 4). Then, two strong endothermic peaks $\mathrm{C}$ and $\mathrm{D}$ are mostly present in R-PC and $\mathrm{W}-\mathrm{PC}$ mortars, due to the carbonates in aggregates, calcite and dolomite. In S-PC, this peak C is almost nonexistent and comes from poorly crystallized carbonates minerals. Between $250^{\circ} \mathrm{C}$ and $600^{\circ} \mathrm{C}$, an exothermic deformation of the DSC curve is observed in R-PC mortar, and to a lesser extent in W-PC 
mortar. This peak corresponds to the calcination of the remaining organic matter, which was also observed with chemical TOC analysis.

\subsubsection{Porewater analysis}

Analysis of porewater extracted from the mortars confirms the occurrence of soluble sulfates, particularly in weathered sediment mortars (Fig. 6). After a short curing period, sulfates are up to $7000 \mathrm{mg} / \mathrm{L}$ in W-PC and W-PCS, whereas in R-PC and R-PCS, concentrations are lower down to $1000 \mathrm{mg} / \mathrm{L}$, and between 100 and $200 \mathrm{mg} / \mathrm{L}$ for reference mortars. At 28 days, sulfate concentrations in porewater decreased for all mortars to $2500-2800 \mathrm{mg} / \mathrm{L}$ for $\mathrm{W}-\mathrm{PC}$ and $\mathrm{W}$ PCS, and 300-600 mg/L for R-PC and R-PCS. For both raw and weathered mortars, sulfate concentrations reached $800-1000 \mathrm{mg} / \mathrm{L}$. In reference mortars, these concentrations did not exceed $200 \mathrm{mg} / \mathrm{L}$. The high concentration of sulfates in weathered mortar porewater agrees with the occurrence of ettringite after 28 days of curing, preventing the formation of AFm phases. In raw mortars, the increase observed between 28 and 90 days might be the result of sulfide oxidation.

Moreover, $\mathrm{pH}$ measured in the porewater of mortars was between 12.2 and 12.7 over the whole curing range. Basicity marginally increased in the porewater of all the samples at 28 days of curing time (increase of about 0.1-0.2 unit). No particular acidification was observed, despite the pHs of reference mortars being slightly higher at 14 and 90 days of curing time than those of weathered and raw mortars.

\section{Discussion}

Technical requirements for the reuse of sediments as an aggregate in cemented mortars will vary depending on the intended use. In this study, the mortars were formulated for a general use for non-structural purposes, such as a cemented slab. Two different reuse management 
strategies for dredged sediment were assessed. Total sediments were formulated so that the whole sediment undergoes a valorization, whereas the processed sediments aimed to reuse the coarse fraction while reducing the amount of contaminated waste to be processed. The fine fraction is the most contaminated part of both weathered and raw sediments, and will require a proper management, although the three metals followed in this study are far more concentrated in this fraction for weathered sediments (Table 3). Hence, the size cut-off at $80 \mu \mathrm{m}$ was chosen to maximize metal removal in accordance with the results of the granulometric content analysis.

A considerable difference in mechanical strength was observed between mortars using total and processed sediments as aggregates and reference mortars on one hand, and between mortars with total sediments and processed sediments on the other hand (Fig 1). The impact of the desliming process is noticeable, as shown by the difference in UCS between mortars formulated with total and processed sediments. At 28 days, the UCS of mortars with total sediments ranged between 2.0 to $2.9 \mathrm{MPa}$, whereas with processed sediments it ranged between 4.1 and 9.0 MPa. At 90 days, the UCS of mortars with total sediments increased up to $3.6 \mathrm{MPa}$, whereas with processed sediments it increased up to $11 \mathrm{MPa}$, even though it remained less than half the resistance of reference mortars. The sieving treatment efficiently improved the mechanical performances of mortars formulated with sediments as aggregates.

Few studies have particularly assessed the mechanical behavior of mortars in which $100 \%$ of sand was replaced by dredged sediments, for valorization purposes. Similar strengths were observed for total sediments, in highly similar operational conditions. Yan \& al. replaced 100\% of sand by coarser sediment in mortars with $25 \%$ of cement. The water demand was noticeably higher, with a W/C of 2.6. As a result, the UCS of the mortars reached 2.5 MPa (Yan et al., 2014). When the cement percentage was increased to $33 \%$ and the $\mathrm{W} / \mathrm{C}$ ratio kept low, close to 0.6 , replacing $100 \%$ of the sand by coarse sediment resulted in a higher mechanical strength. 
With sediments originating from different sources, the UCS reached between 18 to $29 \mathrm{MPa}$ (Ben Allal et al., 2011). To maintain a low W/C, the authors added a plasticizer. Lower mechanical performances are also obtained when lower quantities (60-70\%) of fine sediments are substituted in mortars, with a lower cement proportion of $15-20 \%$, even if the W/C is kept low at close to 0.6. In this case, the UCS reached 1.2-2.1 MPa (Wang et al., 2015). However, for a non-structural purpose such as a pavement base, mechanical requirements are not high. For example, the compressive strength required for controlled low-strength material to make a durable pavement base is between 2.8 and 8.3 MPa (Ramme, 2005).

Mechanical strength comes foremost from the formation of cemented products. The use of marine dredged sediments as aggregates, compared to technical sand, may alter the hydrating processes. Organic matter is especially known to be a component of sediment that can interfere with the hydration process of cement (Tremblay et al., 2002). It was demonstrated that the most acid fraction in particular avoids the formation of $\mathrm{CSH}$ phases by decreasing the $\mathrm{pH}$ of porewater. However, although about 6 wt. $\%$ of TOC were quantified in raw and weathered sediments (Table 2) and the presence of organic matter was confirmed in formulated mortars by thermal analysis (Fig. 5), SEM-EDS observations highlighted that CSH phases are well formed in all the samples analyzed (Fig. 2, Fig. 4). Besides, no acidification was observed in the porewater of mortars. Thus, mineralogy does not explain the degraded mechanical performance of mortars using sediments as aggregates compared to reference mortars.

Porosimetry analysis revealed that the total porosity of mortars formulated with total sediments is higher than the one of mortars formulated with processed sediments, the latter being close to reference mortars, between 15 and 25\% (Fig. 3). Substantial porosity was observed elsewhere for total solidified sediments, varying with the cement proportion and the type of storage (air or mold) (Boutouil and Levacher, 2001). When this porosity is high, mechanical performances 
are heavily impacted. This link between microstructure (porosity), chemical content (bound to water demand) and mechanical strength is clearly correlated as illustrated in Fig. 7. Another study on solidified sediments observed that the increase in total pore area and average pore diameter are linearly correlated with the decrease in compressive strength (Wang et al., 2015). Porosity is linked to initial factors of formulation, in particular to water demand, visible through the $\mathrm{W} / \mathrm{C}$ ratio. In fact, the major part of total porosity is constituted by macropores and mesopores, and comes mainly from water loss upon heating (Paria and Yuet, 2006). Consequently, global porosity usually increases with the W/C ratio. The aggregate used for the formulation may partly influence the water demand, depending on its mineralogical constitution. High concentrations of organic matter and clays, as are usually found in dredged sediments, increase the water demand. In addition to the impact of acid organic matter on CSH formation, humic substances are particularly hydrophilic. Furthermore, organic matter is able to form a very porous aggregate with fine particles, especially clays, and hydrophilic properties lead to retention of 20 times their volume in water (Rekik and Boutouil, 2009).

In the present study, water content decreased when mechanical performances increased (Fig. 7). The removal of fine particles also removed clays and organic matter (according to previous SEDIGest results, OM set preferentially in the fine fraction $<100 \mu \mathrm{m})$, reducing the porosity from $41-44 \%$ to $15-25 \%$. Still, the mechanical performances of mortars with processed sediments are still lower than those of reference mortars. However, a mechanical strength up to $8 \mathrm{MPa}$ enables non-structural applications.

The fineness of sediments could be a problem in the formulation of cemented mortars by replacement of sand. But in contrast, the granulometric skeleton has to be complete to ensure the strength of mortars. Another opportunity is to employ fine fractions of sediments as a fine 
granular corrector, for concrete preparation which uses coarser aggregates (Limeira et al., 2011, 2010).

\section{Conclusion}

This work has aimed to assess the feasibility of reusing dredged sediments to fully replace sand in cemented mortars for use in non-structural applications, such as pavement base. It appears that full substitution of sand by fine total dredged sediments requires a substantial use of mixing water to maintain the workability of mortars. This has a major impact on the mechanical behavior, and strength is low compared to reference mortars. In fact, the substitution by processed sediments with $80 \mu \mathrm{m}$ size cutoff greatly improved the UCS. This treatment offers the possibility to achieve both the reusing of coarse fraction in sand substitution and to improve mechanical strength. Moreover, the use of slag to replace $80 \%$ of standard Portland cement has no substantial short-term effect on strength, although its use is highly recommended in aggressive environments and high sulfate contents to avoid sulfate attack (Rajasekaran, 2005). Cementitious mineral phases (portlandite, ettringite, AFm) were identified, and $\mathrm{CSH}$ in particular were well-formed in all mortars. Total porosity varied between mortars formulated with total and processed sediments, and the increase in porosity is linked to the decrease in UCS. This work falls within the sustainability recommendations of the European Union. The reuse of the coarser fraction is considered as a possible substitute of sand for non-structural applications in cemented mortars, whereas the smaller fine fraction could be reserved for treatment and storage. However, more specific mechanical tests, such as traction tests, should be applied in future stages to fully investigate the potential valorization of sediments in cemented mortars. 


\section{Acknowledgments}

The authors are grateful to the University of Quebec (UQAT) and the Unité de Recherche et de Service en Technologie Minérale (URSTM) for their support in the mineralogical and physicochemical analyses as well as mortar preparations and characterization. The authors' acknowledgments also go to EEDEMS (French research network on waste and polluted materials management) for experimental support. Finally, the authors are grateful to the Région Rhône-Alpes and Université de Lyon for financial support.

\section{References}

Agostini, F., Skoczylas, F., Lafhaj, Z., 2007. About a possible valorisation in cementitious materials of polluted sediments after treatment. Cem. Concr. Compos. 29, 270-278. doi:10.1016/j.cemconcomp.2006.11.012

Akcil, A., Erust, C., Ozdemiroglu, S., Fonti, V., Beolchini, F., 2014. A Review of Approaches and Techniques Used in Aquatic Contaminated Sediments: Metal Removal and Stabilization by Chemical and Biotechnological Processes. J. Clean. Prod. 86, 24-36. doi:10.1016/j.jclepro.2014.08.009

Bapat, J.D., 2012. Mineral Admixtures in Cement and Concrete. CRC Press.

Ben Allal, L., Ammari, M., Frar, I., Azmani, A., Clastres, P., Jullien, S., 2011. Stabilization of contaminated canal sediments. Eur. J. Environ. Civ. Eng. 15, 293-302. doi:10.1080/19648189.2011.9693323

Benzaazoua, M., Fall, M., Belem, T., 2004. A contribution to understanding the hardening process of cemented pastefill. Miner. Eng. 17, 141-152.

doi:10.1016/j.mineng.2003.10.022

Boutouil, M., Levacher, D., 2001. Étude expérimentale de la solidification d'une vase de dragage à base de ciments: évaluation de la porosité et de la structure poreuse après solidification. Mater. Struct. 34, 186-192. doi:10.1007/BF02480510

Bouzahzah, H., Califice, A., Benzaazoua, M., Mermillod-Blondin, R., Pirard, E., AusIMM, 2008. Modal analysis of mineral blends using optical image analysis versus X ray diffraction. 
Caille, N., Tiffreau, C., Leyval, C., Morel, J.L., 2003. Solubility of metals in an anoxic sediment during prolonged aeration. Sci. Total Environ. 301, 239-250. doi:10.1016/S0048-9697(02)00289-9

Calmano, W., Hong, J., Forstner, U., 1993. Binding and mobilization of heavy metals in contaminated sediments affected by $\mathrm{pH}$ and redox potential. Water Sci. Technol.

Caplat, C., Texier, H., Barillier, D., Lelievre, C., 2005. Heavy metals mobility in harbour contaminated sediments: The case of Port-en-Bessin. Mar. Pollut. Bull. 50, 504-511. doi:10.1016/j.marpolbul.2004.08.004

Cappuyns, V., Deweirt, V., Rousseau, S., 2015. Dredged sediments as a resource for brick production: Possibilities and barriers from a consumers' perspective. Waste Manag. 38, 372-380. doi:10.1016/j.wasman.2014.12.025

Carignan, J., Hild, P., Mevelle, G., Morel, J., Yeghicheyan, D., 2001. Routine Analyses of Trace Elements in Geological Samples using Flow Injection and Low Pressure On-Line Liquid Chromatography Coupled to ICP-MS: A Study of Geochemical Reference Materials BR, DR-N, UB-N, AN-G and GH. Geostand. Geoanalytical Res. 25, 187-198. doi:10.1111/j.1751-908X.2001.tb00595.X

Casado-Martínez, M.C., Forja, J.M., DelValls, T. a., 2009. A multivariate assessment of sediment contamination in dredged materials from Spanish ports. J. Hazard. Mater. 163, 1353-1359. doi:10.1016/j.jhazmat.2008.07.106

Chatain, V., Benzaazoua, M., Loustau Cazalet, M., Bouzahzah, H., Delolme, C., Gautier, M., Blanc, D., de Brauer, C., 2013a. Mineralogical study and leaching behavior of a stabilized harbor sediment with hydraulic binder. Environ. Sci. Pollut. Res. 20, 51-59. doi:10.1007/s11356-012-1141-4

Chatain, V., Blanc, D., Borschneck, D., Delolme, C., 2013b. Determining the experimental leachability of copper, lead, and zinc in a harbor sediment and modeling. Environ. Sci. Pollut. Res. 20, 66-74. doi:10.1007/s11356-012-1233-1

Chen, Q.Y., Tyrer, M., Hills, C.D., Yang, X.M., Carey, P., 2009. Immobilisation of heavy metal in cement-based solidification/stabilisation: A review. Waste Manag. 29, 390-403. doi:10.1016/j.wasman.2008.01.019

Chinchón, J., Ayora, C., Aguado, A., Guirado, F., 1995. Influence of weathering of iron sulfides contained in aggregates on concrete durability. Cem. Concr. Res. 25, 12641272 .

Claff, S.R., Burton, E.D., Sullivan, L. a., Bush, R.T., 2010. Effect of sample pretreatment on the fractionation of $\mathrm{Fe}, \mathrm{Cr}, \mathrm{Ni}, \mathrm{Cu}, \mathrm{Mn}$, and $\mathrm{Zn}$ in acid sulfate soil materials. Geoderma 159, 156-164. doi:10.1016/j.geoderma.2010.07.007

Couvidat, J., Benzaazoua, M., Chatain, V., Zhang, F., Bouzahzah, H., 2015. An innovative coupling between column leaching and oxygen consumption tests to assess behavior of 
contaminated marine dredged sediments. Environ. Sci. Pollut. Res. Int. 22, 10943-55. doi:10.1007/s11356-015-4323-Z

Dalton, J.L., Gardner, K.H., Seager, T.P., Weimer, M.L., Spear, J.C.M., Magee, B.J., 2004. Properties of Portland cement made from contaminated sediments. Resour. Conserv. Recycl. 41, 227-241. doi:10.1016/j.resconrec.2003.10.003

Dubois, V., Abriak, N.E., Zentar, R., Ballivy, G., 2009. The use of marine sediments as a pavement base material. Waste Manag. 29, 774-782. doi:10.1016/j.wasman.2008.05.004

Dubois, V., Zentar, R., Abriak, N.-E., Grégoire, P., 2011. Fine sediments as a granular source for civil engineering. Eur. J. Environ. Civ. Eng.

French Official Journal, 2006. Arrêté du 09/08/06 relatif aux niveaux à prendre en compte lors d'une analyse de rejets dans les eaux de surface ou de sédiments marins, estuariens ou extraits de cours d'eau ou canaux publié au JORF n ${ }^{\circ} 222$ du 24 septembre 2006 page 14082 texte $\mathrm{n}^{\circ} 15$.

Gabrovšek, R., Vuk, T., Kaučič, V., 2006. Evaluation of the hydration of Portland cement containing various carbonates by means of thermal analysis. Acta Chim. Slov. 53, 159165.

Gardner, K.H., Tsiatsios, C.J., Melton, J., Seager, T.P., 2007. Leaching behavior of estuarine sediments and cement-stabilized sediments in upland management environments. Waste Manag. 27, 1648-1654. doi:10.1016/j.wasman.2006.09.002

Hamer, K., Karius, V., 2002. Brick production with dredged harbour sediments. An industrial-scale experiment. Waste Manag. 22, 521-530. doi:10.1016/S0956053X(01)00048-4

Harvey, O.R., Harris, J.P., Herbert, B.E., Stiffler, E. a., Haney, S.P., 2010. Natural organic matter and the formation of calcium-silicate-hydrates in lime-stabilized smectites: A thermal analysis study. Thermochim. Acta 505, 106-113. doi:10.1016/j.tca.2010.04.007

Juhasz, A.L., Naidu, R., 2000. Bioremediation of high molecular weight polycyclic aromatic hydrocarbons: A review of the microbial degradation of benzo[a]pyrene. Int. Biodeterior. Biodegrad. 45, 57-88. doi:10.1016/S0964-8305(00)00052-4

Lafhaj, Z., Samara, M., Agostini, F., Boucard, L., Skoczylas, F., Depelsenaire, G., 2008. Polluted river sediments from the North region of France: Treatment with Novosol® process and valorization in clay bricks. Constr. Build. Mater. 22, 755-762. doi:10.1016/j.conbuildmat.2007.01.023

Le Guyader, C., 2013. Enquête “Dragage 2010” - Synthèse des données. CETMEF, Margny Lès Compiègne. 
Limeira, J., Agullo, L., Etxeberria, M., 2010. Dredged marine sand in concrete: An experimental section of a harbor pavement. Constr. Build. Mater. 24, 863-870. doi:10.1016/j.conbuildmat.2009.12.011

Limeira, J., Etxeberria, M., Agulló, L., Molina, D., 2011. Mechanical and durability properties of concrete made with dredged marine sand. Constr. Build. Mater. 25, 41654174. doi:10.1016/j.conbuildmat.2011.04.053

Lions, J., Guérin, V., Bataillard, P., van der Lee, J., Laboudigue, A., 2010. Metal availability in a highly contaminated, dredged-sediment disposal site: field measurements and geochemical modeling. Environ. Pollut. 158, 2857-64. doi:10.1016/j.envpol.2010.06.011

Lions, J., van der Lee, J., Guerin, V., Bataillard, P., Laboudigue, a, 2007. Zinc and cadmium mobility in a 5-year-old dredged sediment deposit: experiments and modelling. J. Soils Sediments 7, 207-215. doi:10.1065/jss2007.05.226

Lovley, D.R., Coates, J.D., 1997. Bioremediation of metal contamination. Curr. Opin. Biotechnol. 8, 285-289. doi:10.1016/S0958-1669(97)80005-5

Matschei, T., Lothenbach, B., Glasser, F.P., 2007. The AFm phase in Portland cement. Cem. Concr. Res. 37, 118-130. doi:10.1016/j.cemconres.2006.10.010

OSPAR commission, 2009. OSPAR guidelines for the management of dredged material.

Paria, S., Yuet, P.K., 2006. Solidification-stabilization of organic and inorganic contaminants using portland cement: a literature review. Environ. Rev. 14, 217-255. doi:10.1139/a06004

Rajasekaran, G., 2005. Sulphate attack and ettringite formation in the lime and cement stabilized marine clays. Ocean Eng. 32, 1133-1159. doi:10.1016/j.oceaneng.2004.08.012

Ramme, B.W., 2005. ACI 229R-99 Controlled Low-Strength Materials. Am. Concr. Inst. 99, $1-15$.

Raudsepp, M., Pani, E., 2003. Application of Rietveld analysis to environmental mineralogy. Environ. Asp. mine wastes. Mineral. Assoc. Canada Short Course 3, 165-180.

Rekik, B., Boutouil, M., 2009. Geotechnical properties of dredged marine sediments treated at high water/cement ratio. Geo-Marine Lett. 29, 171-179. doi:10.1007/s00367-009-0134-x

Samara, M., Lafhaj, Z., Chapiseau, C., 2009. Valorization of stabilized river sediments in fired clay bricks: Factory scale experiment. J. Hazard. Mater. 163, 701-710. doi:10.1016/j.jhazmat.2008.07.153

Sha, W., O’Neill, E. a., Guo, Z., 1999. Differential scanning calorimetry study of ordinary Portland cement. Cem. Concr. Res. 29, 1487-1489. doi:10.1016/S0008-8846(99)001283 
Taylor, H.F.W., 1997. Cement Chemistry.

Tremblay, H., Duchesne, J., Locat, J., Leroueil, S., 2002. Influence of the nature of organic compounds on fine soil stabilization with cement. Can. Geotech. J. 39, 535-546. doi:10.1139/t02-002

Van Hullebusch, E.D., Lens, P.N.L., Tabak, H.H., 2005. Developments in bioremediation of soils and sediments polluted with metals and radionuclides. 3 . Influence of chemical speciation and bioavailability on contaminants immobilization/mobilization bioprocesses. Rev. Environ. Sci. Biotechnol. 4, 185-212. doi:10.1007/s11157-005-2948-y

Wang, D.X., Abriak, N.E., Zentar, R., Xu, W., 2012. Solidification/stabilization of dredged marine sediments for road construction. Environ. Technol. 33, 95-101. doi:10.1080/09593330.2011.551840

Wang, L., Tsang, D.C.W., Poon, C.-S., 2015. Green remediation and recycling of contaminated sediment by waste-incorporated stabilization/solidification. Chemosphere 122, 257-64. doi:10.1016/j.chemosphere.2014.11.071

Xu, Y., Yan, C., Xu, B., Ruan, X., Wei, Z., 2014. The use of urban river sediments as a primary raw material in the production of highly insulating brick. Ceram. Int. 40, 88338840. doi:10.1016/j.ceramint.2014.01.105

Yan, D.Y.S., Tang, I.Y., Lo, I.M.C., 2014. Development of controlled low-strength material derived from beneficial reuse of bottom ash and sediment for green construction. Constr. Build. Mater. 64, 201-207. doi:10.1016/j.conbuildmat.2014.04.087

Young, R.A., 1993. The Rietveld method. Oxford University Press, NYC, NY, USA.

Zentar, R., Wang, D., Abriak, N.E., Benzerzour, M., Chen, W., 2012. Utilization of siliceousaluminous fly ash and cement for solidification of marine sediments. Constr. Build. Mater. 35, 856-863. doi:10.1016/j.conbuildmat.2012.04.024

Zoubeir, L., Adeline, S., Laurent, C.S., Yoann, C., Truc, H.T., Benoît, L.G., Federico, A., 2007. The use of the Novosol process for the treatment of polluted marine sediment. J. Hazard. Mater. 148, 606-612. doi:10.1016/j.jhazmat.2007.03.029 


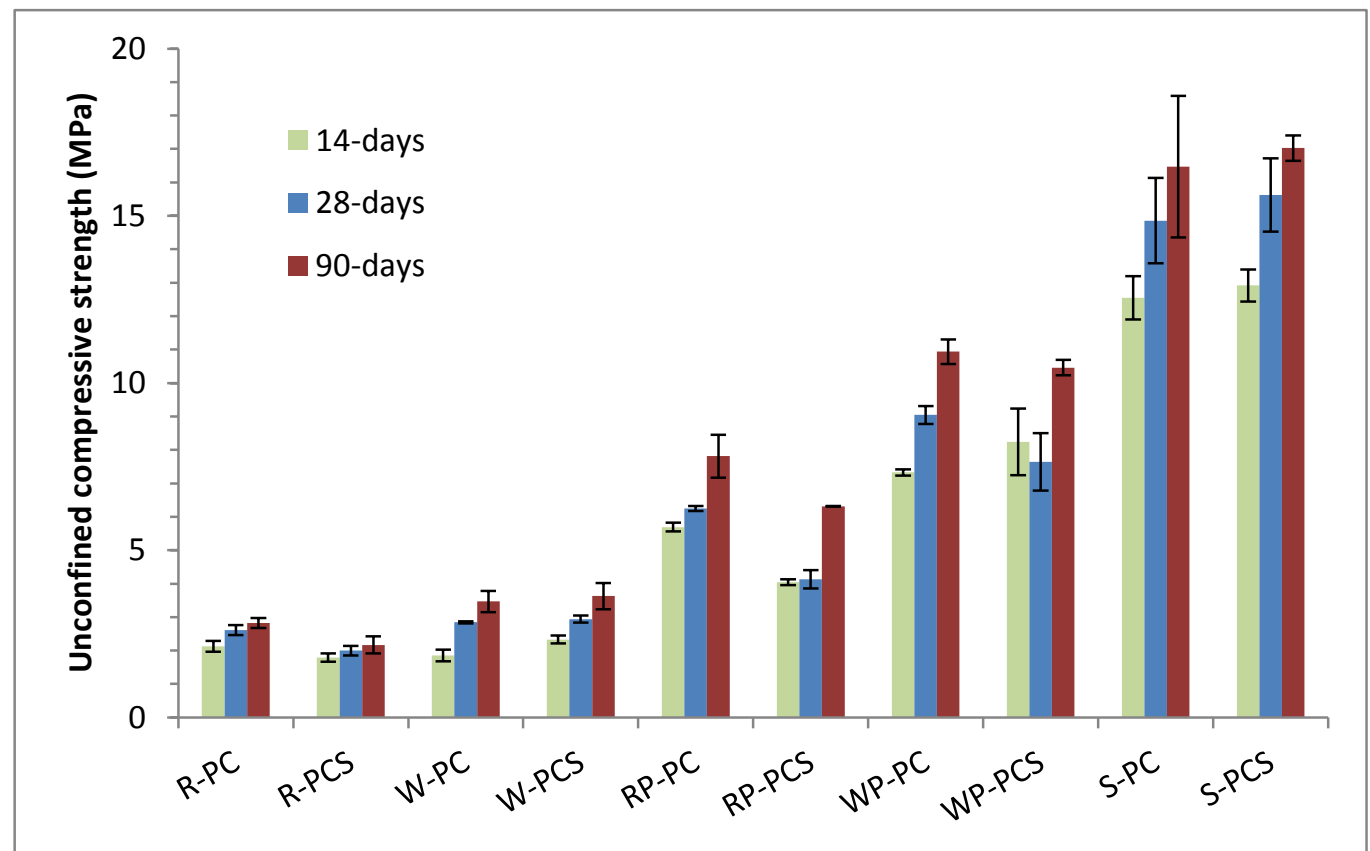

Fig. 1. Evolution of UCS mechanical behavior of mortars with total and processed sediments, and reference mortars, with curing time. 

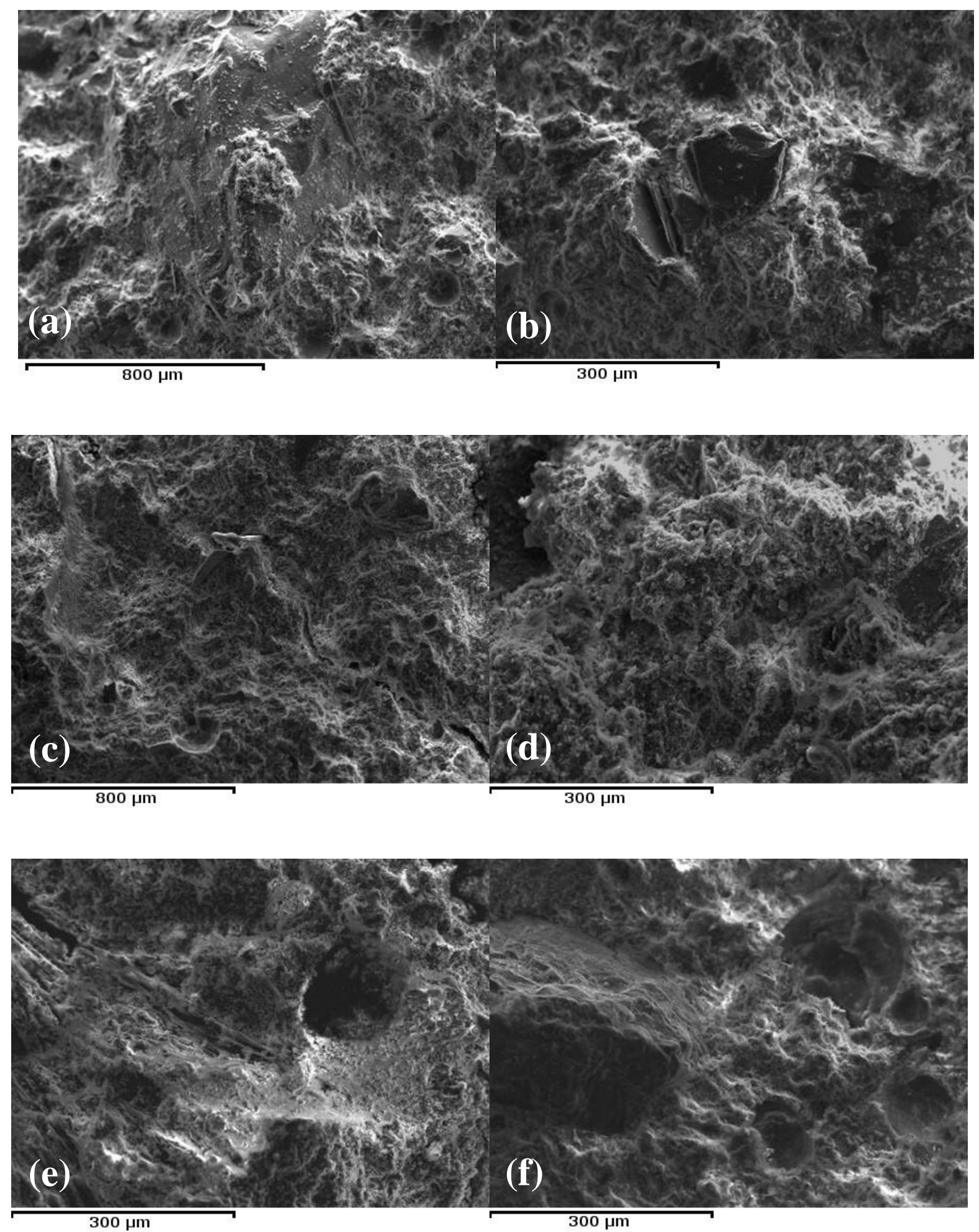

Fig. 2. SEM with back-scattered electron pictures of different mortar samples at 28 days of curing time; S-PC with massive mineral coated by cement hydrates (a), S-PCS with alumino- 
silicates coated by cement hydrates (b), R-PC microstructure detail (c, d), W-PC

microstructure detail (e), and R-PCS alumino-silicate mineral coated with cement hydrates (f).
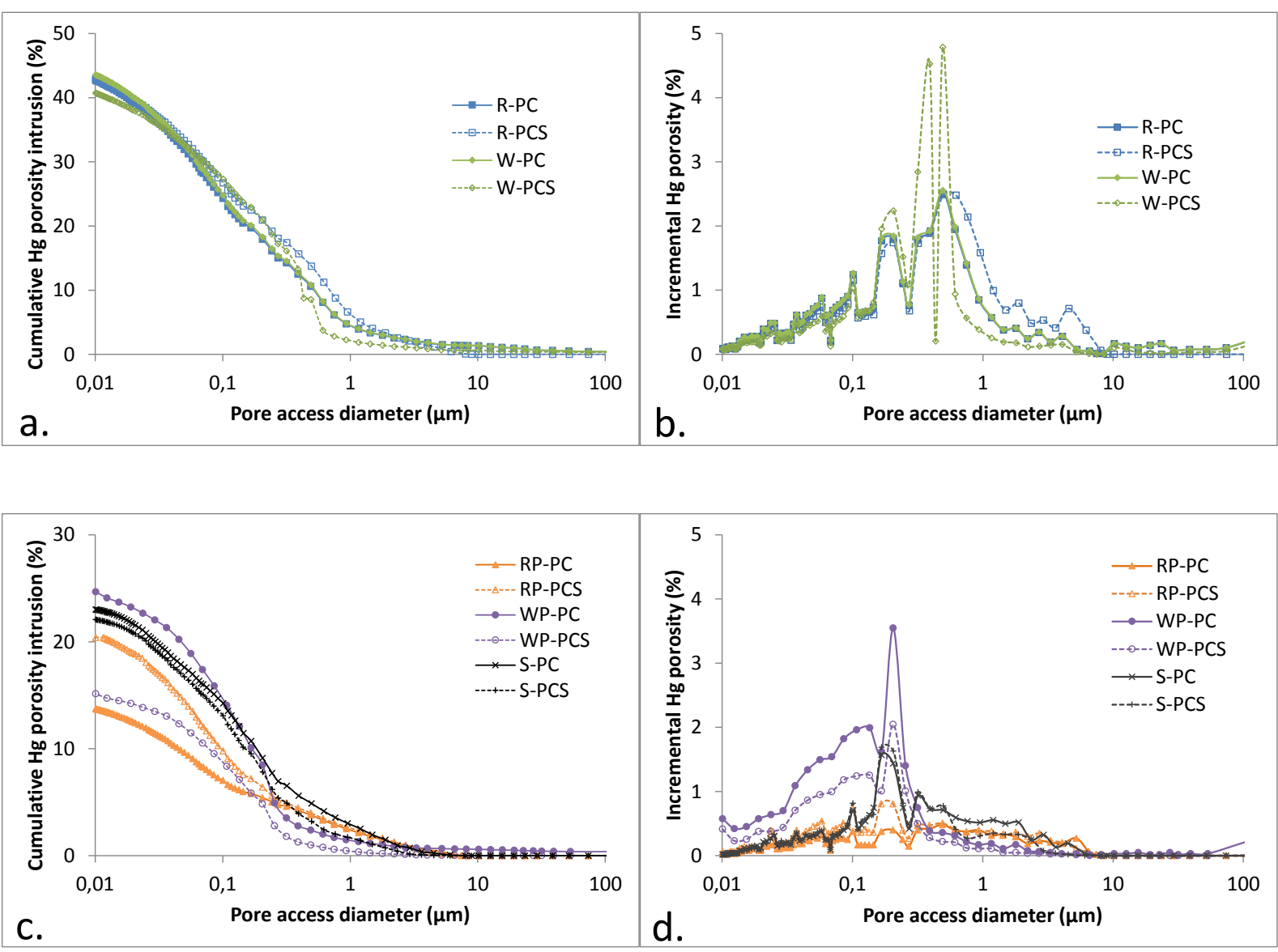

Fig. 3. Cumulative and incremental microporosimetry by $\mathrm{Hg}$ intrusion of total sediments mortars (a, b) and reference and processed deslimed sediments mortars (c, d), at 28 days of curing time. 

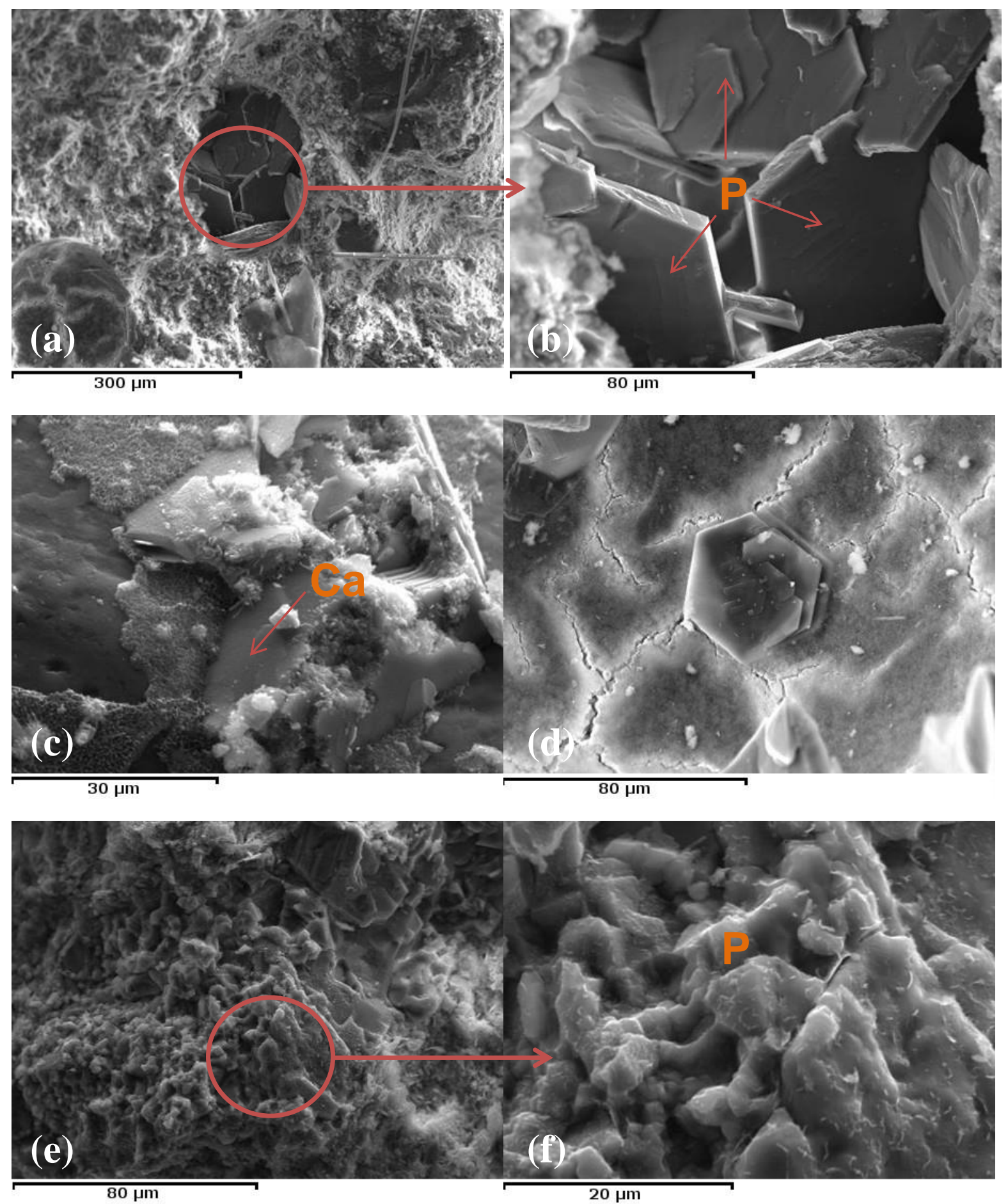




Fig. 4. SEM-EDS with back-scattered electron analysis images of formulated mortars at 28 days : S-PC sample showing a hole filled with thin hexagonal portlandite (P) crystals $(a, b), S-$ PC sample with calcite (Ca) covered with CSH phases (c), S-PC sample with probable AFm hexagonal imbricated phases (d), R-PC sample showing probable entangled portlandite (P) (e, f), and CSH phases and probably ettringite needles on R-PCS sample (g) and W-PC sample (h). 


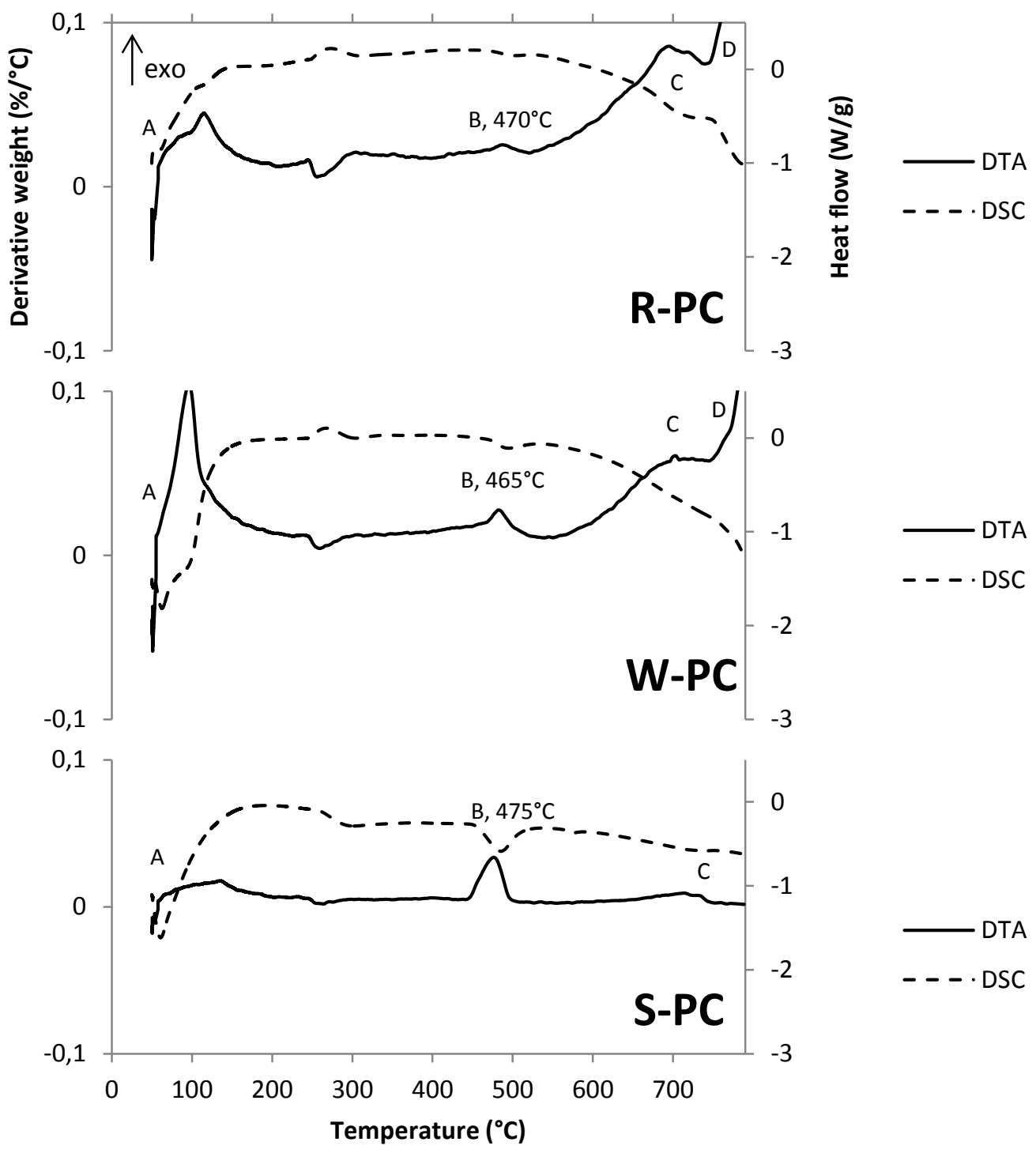

Fig. 5. DTA-DSC spectra of R-PC, W-PC and S-PC mortars at 28 days. 




Fig. 6. Sulfate concentration evolution in mortar porewater of total sediment and reference sand at 14,28 , and 90 days of curing time. 


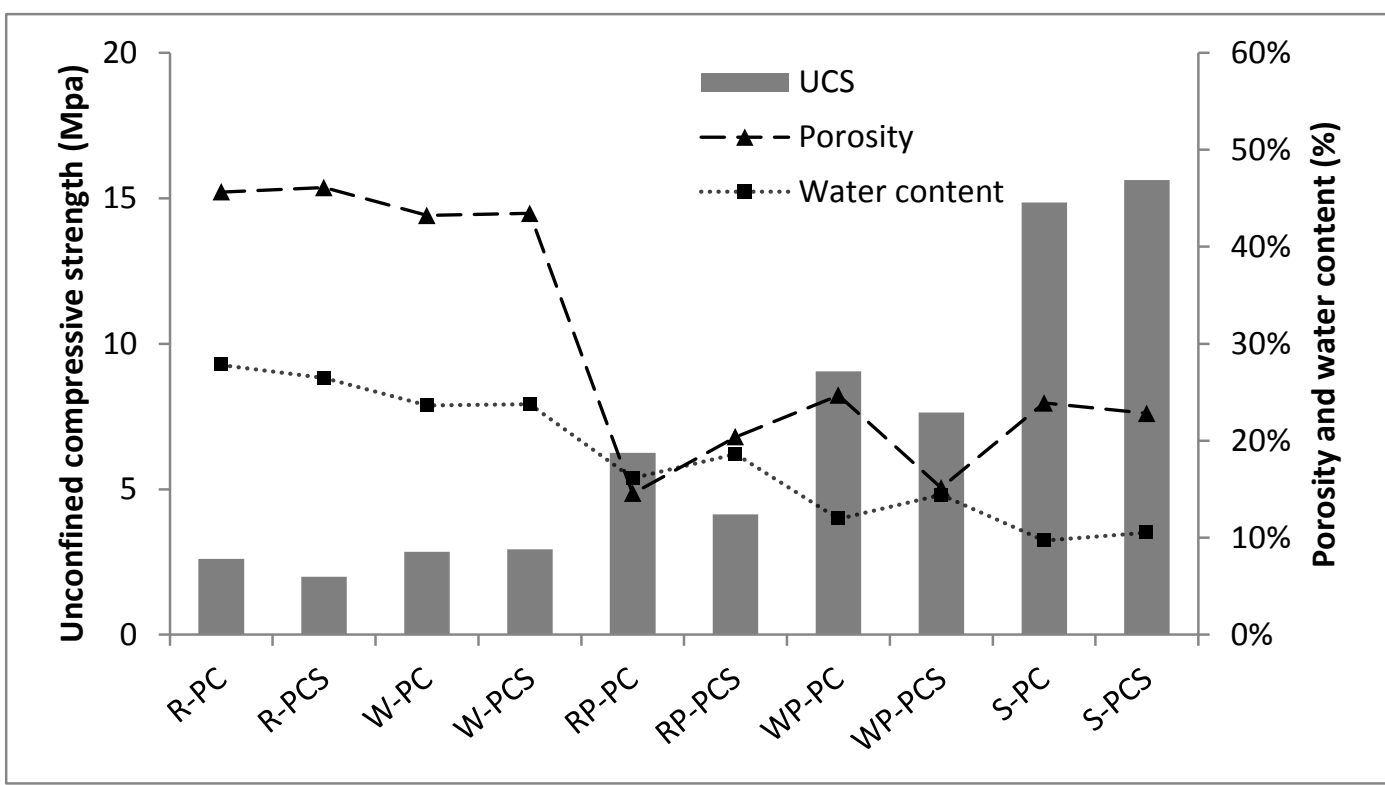

Fig. 7. UCS resistance of total and processed mortars linked to porosity and water content at 28 days of curing time. 
Table 1 Distribution of $\mathrm{Cu}, \mathrm{Pb}$ and $\mathrm{Zn}$ in 6 size fractions.

\begin{tabular}{|c|c|c|c|c|c|c|c|c|}
\hline & & $\begin{array}{l}\text { Sediment mass } \\
\text { proportion }\end{array}$ & & $\mathrm{Cu}$ & & $\mathrm{Pb}$ & & $\mathrm{Zn}$ \\
\hline & & $\%$ & ppm & $\%$ of total & ppm & $\%$ of total & ppm & $\%$ of total \\
\hline & $0-25 \mu \mathrm{m}$ & 53,5 & 1144 & 41,3 & 896 & 53,1 & 1785 & 49,4 \\
\hline & $25-80 \mu \mathrm{m}$ & 7,3 & 1294 & 6,4 & 899 & 7,3 & 1860 & 7,0 \\
\hline 3 & $80-200 \mu \mathrm{m}$ & 7,1 & 2233 & 10,8 & 958 & 7,6 & 2889 & 10,7 \\
\hline$\tilde{\varkappa}$ & $200-1000 \mu \mathrm{m}$ & 13,4 & 3319 & 30,0 & 792 & 11,8 & 3434 & 23,8 \\
\hline & $1-2 \mathrm{~mm}$ & 3,8 & 2754 & 7,1 & 4377 & 18,7 & 2238 & 4,5 \\
\hline & $>2 \mathrm{~mm}$ & 14,8 & 449 & 4,5 & 95 & 1,6 & 597 & 4,6 \\
\hline & $0-25 \mu \mathrm{m}$ & 48,5 & 1656 & 81,8 & 2194 & 84,8 & 2466 & 78,3 \\
\hline 8 & $25-80 \mu \mathrm{m}$ & 5,9 & 1570 & 9,4 & 1570 & 7,3 & 2724 & 10,4 \\
\hline 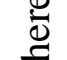 & $80-200 \mu \mathrm{m}$ & 5,0 & 590 & 3,0 & 642 & 2,6 & 1066 & 3,5 \\
\hline$\overline{\tilde{\varpi}}$ & $200-1000 \mu \mathrm{m}$ & 18,7 & 258 & 4,9 & 306 & 4,6 & 532 & 6,5 \\
\hline 3 & $1-2 \mathrm{~mm}$ & 8,7 & 80 & 0,7 & 89 & 0,6 & 157 & 0,9 \\
\hline & $>2 \mathrm{~mm}$ & 13,2 & 15 & 0,2 & 12 & 0,1 & 38 & 0,3 \\
\hline
\end{tabular}


Table 2 Physical, chemical, and mineralogical characteristics of total and processed raw and weathered sediments, and mortar components.

\begin{tabular}{|c|c|c|c|c|c|c|c|c|c|}
\hline & & & Raw & Weath & Raw $>80$ & Weath $>80$ & Portland & Slag & Sand \\
\hline \multirow{6}{*}{ 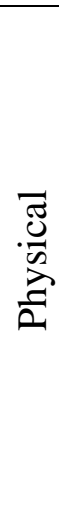 } & Gs & $\mathrm{g} / \mathrm{cm}^{3}$ & 2.5 & 2.6 & 2.5 & 2.7 & 3.1 & 2.9 & 2.7 \\
\hline & $\mathrm{D}_{90}$ & $\mu \mathrm{m}$ & 152.7 & 80.0 & - & - & - & - & - \\
\hline & $\mathrm{D}_{50}$ & $\mu \mathrm{m}$ & 22.1 & 19.2 & - & - & - & - & - \\
\hline & $\begin{array}{l}500 \mu \mathrm{m} \text { mass } \\
\text { fraction }\end{array}$ & wt. $\%$ & 76.6 & 69.4 & - & - & - & - & 83.7 \\
\hline & $\begin{array}{l}63 \mu \mathrm{m} \text { mass } \\
\text { fraction }\end{array}$ & wt. $\%$ & 59.1 & 53.2 & - & - & - & - & 7.2 \\
\hline & $\begin{array}{l}25 \mu \mathrm{m} \text { mass } \\
\text { fraction }\end{array}$ & wt. $\%$ & 53.5 & 48.5 & - & - & - & - & 1.1 \\
\hline \multirow{9}{*}{ 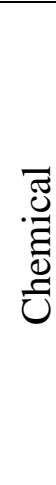 } & $\mathrm{C}$ & wt. $\%$ & 9.3 & 9.9 & - & - & - & - & - \\
\hline & TOC & wt.\% & 5.8 & 6.3 & - & - & - & - & - \\
\hline & $\mathrm{Ca}$ & wt.\% & 13.9 & 19.7 & 16.0 & 26.8 & 44.3 & 28.1 & 1.91 \\
\hline & $\mathrm{Fe}$ & wt. $\%$ & 3.72 & 3.38 & 3.55 & 1.88 & 2.07 & 0.46 & 4.17 \\
\hline & $\mathrm{Mg}$ & wt. $\%$ & 1.64 & 2.07 & 1.05 & 1.97 & 0.92 & 3.85 & 0.29 \\
\hline & $\mathrm{S}$ & wt.\% & 1.89 & 2.02 & 1.13 & 0.96 & 2.85 & 1.44 & $<\mathrm{LOD}$ \\
\hline & $\mathrm{Cu}$ & $\mathrm{mg} / \mathrm{kg}$ & 1445 & 835 & 2048 & 276 & 67 & $<$ LOD & $<\mathrm{LOD}$ \\
\hline & $\mathrm{Pb}$ & $\mathrm{mg} / \mathrm{kg}$ & 760 & 1260 & 666 & 210 & $<\mathrm{LOD}$ & $<$ LOD & $<$ LOD \\
\hline & $\mathrm{Zn}$ & $\mathrm{mg} / \mathrm{kg}$ & 2085 & 2550 & 2445 & 429 & 527 & 17 & 43 \\
\hline \multirow{12}{*}{ 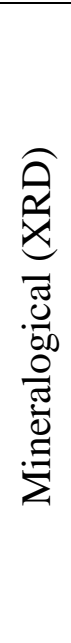 } & Quartz & wt.\% & 15.7 & 15.3 & - & - & - & - & - \\
\hline & Muscovite & wt.\% & $<\mathrm{LOD}$ & 9.2 & - & - & - & - & - \\
\hline & Chamosite & wt.\% & 6.5 & 4.5 & - & - & - & - & - \\
\hline & Illite & wt. $\%$ & 13.2 & 1.6 & - & - & - & - & - \\
\hline & Kaolinite & wt. $\%$ & 9.8 & 4.0 & - & - & - & - & - \\
\hline & Dolomite & wt. $\%$ & 6.8 & 13.6 & - & - & - & - & - \\
\hline & Calcite & wt. $\%$ & 31.1 & 38.9 & - & - & - & - & - \\
\hline & Halite & wt. $\%$ & 3.8 & 0.8 & - & - & - & - & - \\
\hline & Pyrite & wt. $\%$ & 3.5 & 2.0 & - & - & - & - & - \\
\hline & Chalcopyrite & wt. $\%$ & 0.3 & $<\mathrm{LOD}$ & - & - & - & - & - \\
\hline & Magnétite & wt.\% & 0.2 & 1.1 & - & - & - & - & - \\
\hline & Gypse & wt. $\%$ & $<\mathrm{LOD}$ & 5.0 & - & - & - & - & - \\
\hline
\end{tabular}


Table 3 Mortar recipes and preparation characteristics.

\begin{tabular}{ccccccc}
\hline Aggregate & $\begin{array}{c}\text { Portland } \\
\text { cement } \\
\%\end{array}$ & $\begin{array}{c}\text { Slag } \\
\%\end{array}$ & $\begin{array}{c}\text { Cement } \\
\text { proportion } \\
\%\end{array}$ & W/C & Slump \\
\hline R-PC & Raw & 100 & 0 & 25.00 & 2.50 & 62 \\
R-PCS & Raw & 20 & 80 & 25.01 & 2.34 & 60 \\
W-PC & Weath. & 100 & 0 & 25.00 & 2.11 & 61 \\
W-PCS & Weath. & 20 & 80 & 25.00 & 2.14 & 59 \\
S-PC & Sand & 100 & 0 & 25.00 & 0.87 & 62 \\
S-PCS & Sand & 20 & 80 & 25.00 & 0.96 & 60 \\
RP-PC & Raw $>80 \mu$ & 100 & 0 & 24.76 & 1.53 & 63 \\
RP-PCS & Raw $>80 \mu$ & 20 & 80 & 25.03 & 1.47 & 62 \\
WP-PC & Weath $>80 \mu$ & 100 & 0 & 25.04 & 1.06 & 60 \\
WP-PCS & Weath $>80 \mu$ & 20 & 80 & 25.00 & 1.17 & 63 \\
\hline
\end{tabular}


Table 4 XRD analyses of mortars with total sediment and reference sand at 28 days of curing time.

\begin{tabular}{lcccccc}
\hline & R-PC & R-PCS & W-PC & W-PCS & S-PC & S-PCS \\
\hline Quartz & $\mathrm{x}$ & $\mathrm{x}$ & $\mathrm{x}$ & $\mathrm{x}$ & $\mathrm{x}$ & $\mathrm{x}$ \\
Calcite & $\mathrm{x}$ & $\mathrm{x}$ & $\mathrm{x}$ & $\mathrm{x}$ & Traces & Traces \\
Dolomite & $\mathrm{x}$ & $\mathrm{x}$ & $\mathrm{x}$ & $\mathrm{x}$ & - & - \\
Muscovite & $\mathrm{x}$ & $\mathrm{x}$ & $\mathrm{x}$ & $\mathrm{x}$ & - & - \\
Pyrite & $\mathrm{x}$ & $\mathrm{x}$ & Traces & Traces & - & - \\
Chalcopyrite & Traces & - & Traces & Traces & - & - \\
Sulfates & $\mathrm{x}$ & $\mathrm{x}$ & - & - & - & - \\
Halite & $\mathrm{x}$ & - & - & - & - & - \\
Chlorite & - & Traces & $\mathrm{x}$ & $\mathrm{x}$ & - & - \\
Ettringite & - & - & $\mathrm{x}$ & $\mathrm{x}$ & - & - \\
Portlandite & - & - & $\mathrm{x}$ & $\mathrm{x}$ & $\mathrm{x}$ & $\mathrm{x}$ \\
\hline minerals were not identified in aggregates or cement constituents
\end{tabular}

${ }^{1}$ These sulfate minerals were not identified in aggregates or cement constituents 